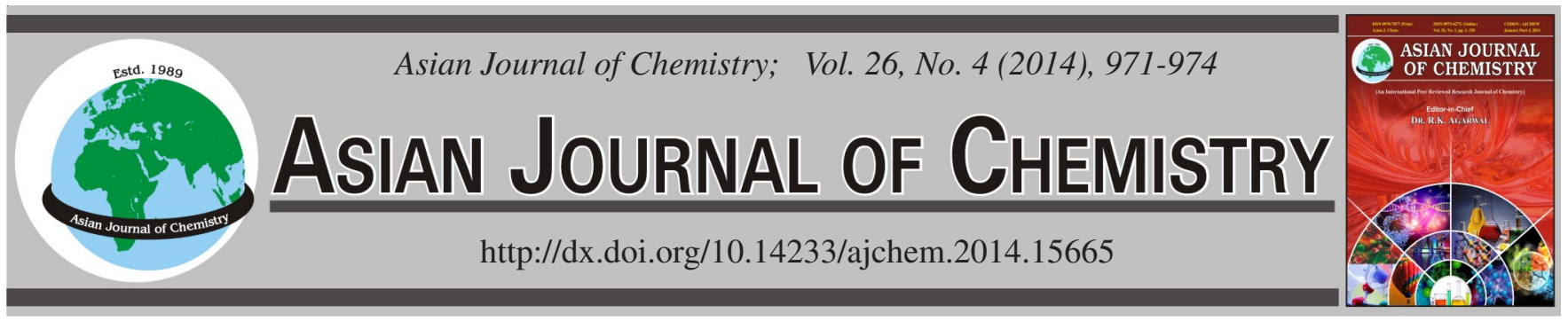

\title{
Reactions of Methyl Acetylenecarboxylate with Heterocyclic Enamines: [2+2] Cycloadditions in Polar and Non-Polar Solvents
}

\author{
Nesimi Uludag ${ }^{1, *}$, OKtay Asutay ${ }^{2}$ and Medet Yakup ${ }^{1}$ \\ ${ }^{1}$ Department of Chemistry, Faculty of Arts and Sciences, Namik Kemal University, 59030 Tekirdag, Turkey \\ ${ }^{2}$ Department of Chemistry, Muratli Vocational School, Namik Kemal University, Muratli, Tekirdag, Turkey \\ *Corresponding author: E-mail: nuludag@ nku.edu.tr
}

Received: 22 April 2013;

Accepted: 9 September 2013;

Published online: 15 February 2014;

AJC-14681

In this study, enamines of cyclic ketones reacting with methyl acetylenecarboxylate to produce intermadiate cyclobutene adducts have
been isolated. Reactions of methyl acetylenecarboxylate with enamines derived from cyclobutene adducts and ring expansion products
were described.

Keywords: Cyclic enamine, Methyl acetylenecarboxylate, [2+2] Cycloaddition.

\section{INTRODUCTION}

$[2+2]$ Cycloaddition reactions of enamines of cyclic ketones and electron-deficient acetylene folowed by thermal rearrangement of the resulting fused cyclobutenes are important in organic syntheses. Reactions of enamines of cyclic ketones with electrophilic olefins yield ring-expanded products, such as 1-(N-morpholino)cyclohexene, 1-(N-pyyrolidinyl) cyclohexene and 1-(N-piperidinyl)cyclohexene with methyl acrylate, methyl acetylene dicarboxylate, dimethyl acetylenedicarboxylate and diethyl acetylenedicarboxylate by an analogous process which has been extensively studied in the literature ${ }^{1-4}$.

Since the relatively generel procedure for the alkylation of carbonyl compoundds via their enamines derivatives are introduced by many workers ${ }^{5-8}$. The reactions of the latter with a wide variety of electrophiles have been widely studied $^{9}$.

The [2+2] cycloadditions of enamines with electrophilic acetylenes in polar and Non-polar solvents are well documented and represent an important strategy for the synthesis of cyclobutene derivatives ${ }^{6}$. Moreover, the thermal rearrangement of this type of cyclobutenes is a useful method for ring enlargement with two carbon atoms and has been widely used in the syntheses of azulene and alkaloids ${ }^{7,8}$ and several natural products $^{10,11}$.

Bose and Minah ${ }^{12}$ and Bercholed ${ }^{1}$ have been reported the reactions of enamines of cyclic ketones with methyl acetylenecarboxylate and with dimethyl acetyelenecarboxylate to yield ring-expanded products by an analogous process. Heubner et al. ${ }^{4}$ have also reported the reactions of enamines with ethyl acetylenecarboxylate which were carried out by addition of the esters to a dioxane solution of 1-pyrrolidinocyclopentene at an ambient temperature, in similar cases.

We reported herein the cycloaddition reactions of enamines with methyl acetylenecarboxylate in different solvents, benzene and methanol, respectively.

In addition, we have found that polar solvents, such methyl acetylenecarboxylate, behave differently to yield a pyrrolizine derivative. Not only does the polarity of the solvent affect the course of the reactions, but both as methanol is used, the reactions of pyrrolidine, morpholine and piperidine enamine with the structure of the enamines and type of acetylenes may also alter the course of the reaction.

\section{EXPERIMENTAL}

All melting points were measured in sealed tubes using an electrothermal digital melting points apparatus (Gallenkamp) and uncorrected. FT-IR spectra were recorded on a Mattson 1000 spectrometer. ${ }^{1} \mathrm{H}$ NMR (400) spectra were recorded with Bruker instrument DPX-400, $400 \mathrm{MHz}$ high performance digital FT-NMR spectrometer by using $\mathrm{CDCl}_{3}$ and DMSO as a solvents and tetramethylsilane (TMS) an internal standart at $25^{\circ} \mathrm{C}$, respectively. Chemical shifts are expressed in terms of parts per million $(\delta)$ and coupling constants are given in $\mathrm{Hz}$. Reactions were monitored by thin layer chromatography (silica gel $60 \mathrm{~F}_{254}$ ). Purifications of solvents were performed according to standard methods.

Methyl 1-(N-morpholinyl)bicyclo[4.2.0]octene 8carboxylate (2) and methyl 2-(N-morpholinyl)-1,7- 
cyclooctadiene-1-carboxylate (3): Methyl acetylenecarboxylate $1.2 \mathrm{~mL}(14.35 \mathrm{mmol})$ in $50 \mathrm{~mL}$ of benzene was added slowly over a period of $2 \mathrm{~h}$ under nitrogen to a solution of $1.2 \mathrm{~g}$ ( $7.17 \mathrm{mmol})$ of $1-\left(\mathrm{N}\right.$-morpholinyl)cyclohexene at $0-7^{\circ} \mathrm{C}$. The reaction mixture was stirred for $2 \mathrm{~h}$ at $0{ }^{\circ} \mathrm{C}$ and then stirring was continued for $42 \mathrm{~h}$ at room temperature. The solvent was evaporated off and the residue was chromatographed using silica gel and dichloromethane-ethyl acetate $(2: 1)$, which yielded a mixture of $\mathbf{2}$ and $\mathbf{3}$, as a brown oil (1.148 g). The ratio of $\mathbf{2}$ and $\mathbf{3}$ was determined by GC-MS analysis as $35 \%$ of 2 and $65 \%$ of 3 . The mixture was separated by column chromatography using dichloromethane-ethylacetate (2:1). The crude product, methyl 1-(N-morpholinyl)bicyclo[4.2.0]octene 8-carboxylate 2 , was recrystallized from ethyl acetate to afford of $0.326(18 \%)$, m.p. $86^{\circ} \mathrm{C}$; TLC: $\mathrm{R}_{\mathrm{f}} 0.65$ [dichloromethane]. Methyl 2-(N-morpholinyl)-1,7-cyclooctadiene-1carboxylate $\mathbf{3}$ was recrystallized from petroleum ether to give $0.822(45 \%) 3$ as a white solid, m.p. $81^{\circ} \mathrm{C}$; TLC: $\mathrm{R}_{\mathrm{f}} 0.8$ [ethyl acetate].

Methyl 1-(N-morpholinyl)bicyclo[4.2.0]octene 8carboxylate (2): IR $\left(\mathrm{KBr}, \mathrm{v}_{\max }, \mathrm{cm}^{-1}\right)$ : 2973( $\left.\mathrm{N}-\mathrm{C}\right), 2943\left(\mathrm{CH}_{2}\right)$, $1697(\mathrm{C}=\mathrm{O}), 1644 \mathrm{C}=\mathrm{CH}, 1173(\mathrm{C}-\mathrm{O}) \mathrm{cm}^{-1} ;{ }^{1} \mathrm{H} \mathrm{NMR}\left(\mathrm{CDCl}_{3}\right)$ : $\delta 7.36(\mathrm{dd}, 1 \mathrm{H}, \mathrm{C}=\mathrm{CH}, J=13.02 \mathrm{~Hz}$ and $J=1.92 \mathrm{~Hz}), 4.2-3.8$ $(\mathrm{m}, 1 \mathrm{H}, \mathrm{CH}), 3.75\left(\mathrm{~s}, 3 \mathrm{H}, \mathrm{OCH}_{3}\right), 3.62-3.55(\mathrm{~m}, 4 \mathrm{H}$, $\left.\mathrm{NCH}_{2} \mathrm{CH}_{2} \mathrm{CH}_{2}\right), 3.26-3.20\left(\mathrm{~m}, 4 \mathrm{H}, \mathrm{N}\left(\mathrm{CH}_{2}\right)_{2}\right), 1.67-1.25(\mathrm{~m}$, $8 \mathrm{H}, \mathrm{CH}_{2}$ ). MS $70 \mathrm{eV}, \mathrm{m} / \mathrm{z} 251.3$ (100) $\left[\mathrm{M}^{+}\right], 236$ (11), 222 (47), 208 (28), 192 (92), 178 (33), 164 (58). Anal. calcd. (\%) for $\mathrm{C}_{14} \mathrm{H}_{21} \mathrm{NO}_{3}: \mathrm{C}, 66.80 ; \mathrm{H} \mathrm{8.33;} \mathrm{N,} 5.60$ Found (\%): C, 66.76; $\mathrm{H}, 8.35 ; \mathrm{N}, 5.65$.

Methyl 2-(N-morpholinyl)-1,7-cyclooctadiene-1carboxylate (3): $\mathrm{IR}\left(\mathrm{KBr}, \nu_{\max }, \mathrm{cm}^{-1}\right)$ : 2955(N-C), 2961 $\left(\mathrm{CH}_{2}\right)$, $1716(\mathrm{C}=\mathrm{O}), 1617 \mathrm{C}=\mathrm{CH}, 1213(\mathrm{C}-\mathrm{O}) \mathrm{cm}^{-1} ;{ }^{1} \mathrm{H} \mathrm{NMR}\left(\mathrm{CDCl}_{3}\right)$ : $\delta 7.23(\mathrm{dd}, 1 \mathrm{H}, \mathrm{C}=\mathrm{CH}, J=18.6$ and $J=12.16 \mathrm{~Hz}), 7.00(\mathrm{dd}$, $1 \mathrm{H}, \mathrm{C}=\mathrm{CH}, J=7.52$ and $J=7.48 \mathrm{~Hz}), 3.77\left(\mathrm{~s}, 3 \mathrm{H}, \mathrm{OCH}_{3}\right)$ 3.65-3.60 (m, 4H, $\left.\mathrm{NCH}_{2}\left(\mathrm{CH}_{2}\right)_{2}\right), 3.31-3.28\left(\mathrm{~m}, 4 \mathrm{H}, \mathrm{NCH}_{2} \mathrm{CH}_{2}\right)$, 1.8-1.25 (m, 8H, $\left.\mathrm{CH}_{2}\right)$; MS $70 \mathrm{eV}, \mathrm{m} / \mathrm{z} 251.2$ (100) $\left[\mathrm{M}^{+}\right], 236$ (18), 222 (25), 208 (42), 194 (84), 178 (15), 164 (26), 148 (39), 134 (46). Anal. calcd. (\%) for $\mathrm{C}_{14} \mathrm{H}_{21} \mathrm{NO}_{3}$ : C, 66.84; $\mathrm{H}$, 8.35; N 5.57. Found (\%): C, 66.80; H, 8.38; N, 5.60.

Methyl 2-(N-morpholinyl)-1,7-cyclooctadiene-1-carboxylate (3): Methyl acetylenecarboxylate $1.2 \mathrm{~mL}(14.35$ $\mathrm{mmol}$ ) in $50 \mathrm{~mL}$ of methanol was added slowly over a period of $2 \mathrm{~h}$ under nitrogen to a solution of $1.2 \mathrm{~g}(7.17 \mathrm{mmol})$ of 1(N-morpholinyl)cyclohexene at $0-7^{\circ} \mathrm{C}$. The reaction mixture was stirred for $2 \mathrm{~h}$ at $0{ }^{\circ} \mathrm{C}$ and then stirring was continued for $35 \mathrm{~h}$ at room temperature. The solvent was evaporated and the residue was purified by column chromatography using silica gel dichlorometane-ethyl acetate $(2: 1)$ to afford $1.4 \mathrm{~g} \mathrm{(72 \% )}$ of 3, m.p. $81{ }^{\circ} \mathrm{C}$; TLC: $\mathrm{R}_{\mathrm{f}} 0.51$ [dichloromethane-ethyl acetate, (2:1)]; IR (KBr, $\left.v_{\max }, \mathrm{cm}^{-1}\right)$ : 3008(N-C), $2961\left(\mathrm{CH}_{2}\right)$, $1723(\mathrm{C}=\mathrm{O}), 1644 \mathrm{C}=\mathrm{CH}, 1207(\mathrm{C}-\mathrm{O}) ;{ }^{1} \mathrm{H}{ }^{1} \mathrm{H}$ NMR $\left(\mathrm{CDCl}_{3}\right)$ : $\delta 7.23(\mathrm{dd}, 1 \mathrm{H}, \mathrm{C}=\mathrm{CH}, J=18.6$ and $J=12.16 \mathrm{~Hz}), 7.00(\mathrm{dd}$, $1 \mathrm{H}, \mathrm{C}=\mathrm{CH}, J=7.52$ and $J=7.48 \mathrm{~Hz}), 3.77\left(\mathrm{~s}, 3 \mathrm{H}, \mathrm{OCH}_{3}\right)$ 3.65-3.60 (m, 4H, $\left.\mathrm{NCH}_{2}\left(\mathrm{CH}_{2}\right)_{2}\right), 3.31-3.28\left(\mathrm{~m}, 4 \mathrm{H}, \mathrm{NCH}_{2} \mathrm{CH}_{2}\right)$, 1.8-1.25 (m, 8H, $\left.\mathrm{CH}_{2}\right)$; MS 70 eV, m/z 251.2 (100) [ $\left.\mathrm{M}^{+}\right], 236$ (18), 222 (25), 208 (42), 194 (84), 178 (15), 164 (26), 148 (39), 134 (46). Anal. calcd. (\%) for $\mathrm{C}_{14} \mathrm{H}_{21} \mathrm{NO}_{3}$ : C, 66.83; $\mathrm{H}$, 8.34; N, 5.59 Found (\%): C, 66.82; H, 8.36; N, 5.63.
Methyl 1-(N-piperidinyl)bicyclo[4.2.0]octene-8carboxylate (5): Methylacetylenecarboxylate $1.2 \mathrm{~mL}$ (14.35 $\mathrm{mmol}$ ) in $50 \mathrm{~mL}$ of benzene was added slowly over a period of $2 \mathrm{~h}$ under nitrogen to a solution of $1.2 \mathrm{~g}(7.17 \mathrm{mmol})$ of 1 (N-piperidin) cyclohexene at $0-7^{\circ} \mathrm{C}$. The reaction mixture was stirred for $2 \mathrm{~h}$ at $0{ }^{\circ} \mathrm{C}$ and then stirring was continued for $32 \mathrm{~h}$ at room temperature. The solvent was evaporated and the residue was purified by column chromatography using silica gel dichlorometane-ethyl acetate $(2: 1)$ to afford $0.75 \mathrm{~g} \mathrm{(42 \% )}$ of 5, TLC: $\mathrm{R}_{\mathrm{f}}$ : 0.51 [dichloromethane-ethyl acetate, (2:1)]; m.p.: $92^{\circ} \mathrm{C}$; IR (KBr, $\left.v_{\max }, \mathrm{cm}^{-1}\right): 2971(\mathrm{~N}-\mathrm{C}), 2902\left(\mathrm{CH}_{2}\right), 1697$ $(\mathrm{C}=\mathrm{O}), 1646 \mathrm{C}=\mathrm{CH}, 1113(\mathrm{C}-\mathrm{O}) \mathrm{cm}^{-1} ;{ }^{1} \mathrm{H}$ NMR $\left(\mathrm{CDCL}_{3}\right): \delta$ $7.38(\mathrm{~d}, 1 \mathrm{H}, \mathrm{C}=\mathrm{CH}, J=13.02 \mathrm{~Hz}), 4.55-4.35(\mathrm{~m}, 1 \mathrm{H}, \mathrm{CH}), 3.85$ (s, 3H, $\mathrm{OCH}_{3}$ ), 3.72-3.67 (m, 4H, $\mathrm{NCH}_{2} \mathrm{CH}_{2}$ ), 3.22-3.20 (m, $\left.8 \mathrm{H}, \mathrm{CH}_{2} \mathrm{CH}_{2} \mathrm{CH}_{2} \mathrm{CH}_{2} \mathrm{CH}_{2} \mathrm{CH}_{2} \mathrm{CH}_{2} \mathrm{CH}_{2}\right),\left(\mathrm{m}, 6 \mathrm{H}, \mathrm{NCH}_{2} \mathrm{CH}_{2}\right)$; MS 70 eV, m/z 251.2 (37) [ $\left.\mathrm{M}^{+}\right], 192$ (29), 178 (100), 132 (10), 77 (13). Anal. calcd. (\%) for $\mathrm{C}_{15} \mathrm{H}_{23} \mathrm{NO}_{2}$ : C, 72.25; $\mathrm{H}$, 9.30; N, 5.62 Found (\%): C, 72.21; H, 9.34; N, 5.68.

Methyl 2-(N-piperidinyl)1-7-cyclooxtadiene-1carboxylate (6): Compound $51.5 \mathrm{~g}(6.02 \mathrm{mmol})$ was refluxed in 1,4-dioxane for $8 \mathrm{~h}$. After the solvent was evaporated off and the residue was chromatgraphed using silica gel with dichlorometane-ethyl acetate $(2: 1)$. The crude products was recrystallized from diethyl ether to give $0.95 \mathrm{~g}(67 \%) 6$ as a pure white solid, m.p. $98^{\circ} \mathrm{C}$; TLC: $\mathrm{R}_{\mathrm{f}} 0.73$ (ethyl acetate); IR $\left(\mathrm{KBr}, \mathrm{v}_{\max }, \mathrm{cm}^{-1}\right): 2986(\mathrm{~N}-\mathrm{C}), 2970\left(\mathrm{CH}_{2}\right), 1710(\mathrm{C}=\mathrm{O}), 1650$ $\mathrm{C}=\mathrm{CH}, 11150(\mathrm{C}-\mathrm{O}) ;{ }^{1} \mathrm{H}$ NMR $\left(\mathrm{CDCl}_{3}\right): \delta 7.58-7.26(\mathrm{dd}, 1 \mathrm{H}$, $\mathrm{C}=\mathrm{CH}, J=12.01$ and $J=4.52 \mathrm{~Hz}), 5.67(\mathrm{~d}, 1 \mathrm{H}, J=12.36 \mathrm{~Hz}$, $\mathrm{C}=\mathrm{CH}), 3.75\left(\mathrm{~s}, 3 \mathrm{H}, \mathrm{OCH}_{3}\right), 3.70-3.74\left(\mathrm{~m}, 4 \mathrm{H}, \mathrm{N}\left(\mathrm{CH}_{2}\right)_{2}\right)$, 2.69-2.43 (m, 6H, $\left.\mathrm{NCH}_{2} \mathrm{CH}_{2} \mathrm{CH}_{2} \mathrm{CH}_{2}\right), 2-17-1.2,(8 \mathrm{H}$, $\mathrm{CH}_{2} \mathrm{CH}_{2} \mathrm{CH}_{2} \mathrm{CH}_{2}$ ). Anal. calcd. (\%) for $\mathrm{C}_{15} \mathrm{H}_{23} \mathrm{NO}_{2}$ : C, 72.18; H, 9.22; N, 5.61. Found (\%): C, 72.23; H, 9.18; N, 5.65.

10-Ethyl-1,2,3,4,6,7,8,9,9a,10-decahydropyrido[1,2a]indole (7): Methyl acetylenecarboxylate $1.2 \mathrm{~mL}(14.35$ $\mathrm{mmol}$ ) in $50 \mathrm{~mL}$ of methanol was added slowly over a period of $2 \mathrm{~h}$ under nitrogen to solution of $1.2 \mathrm{~g}(7.17 \mathrm{mmol})$ of 1 (N-piperidin) cyclohexene at $0-7^{\circ} \mathrm{C}$. The reaction mixture was stirred for $2 \mathrm{~h}$ at $0{ }^{\circ} \mathrm{C}$ and then stirring was continued for $18 \mathrm{~h}$ at room temperature. The solvent was evaporated. The residue purified by chromatography using silica gel dichlorometaneethyl acetate (2:1) to afford $0.8 \mathrm{~g}(44 \%)$ of 7 , TLC: $\mathrm{R}_{\mathrm{f}} 0.70$ (ethyl acetate); m.p. $110^{\circ} \mathrm{C}$; IR $\left(\mathrm{KBr}, \nu_{\max }, \mathrm{cm}^{-1}\right): 2980(\mathrm{~N}-\mathrm{C})$, $2976\left(\mathrm{CH}_{2}\right), 1710(\mathrm{C}=\mathrm{O}), 1630 \mathrm{C}=\mathrm{CH}, 1150(\mathrm{C}-\mathrm{O}) ;{ }^{1} \mathrm{H}{ }^{1} \mathrm{H}$ $\mathrm{NMR}\left(\mathrm{CDCl}_{3}\right): \delta 7.20-6.70\left(\mathrm{~d}-\mathrm{d}, 2 \mathrm{H}, \mathrm{CH}-\mathrm{CH}_{2}-\mathrm{CO}_{2} \mathrm{CH}_{3}\right), 3.81$ (s, 3H, $\left.\mathrm{OCH}_{3}\right), 3.71-3.6$ (m, 3H, NCH, $\left.\mathrm{NCH}_{2}\right), 2.69-2.65(\mathrm{t}$, $\left.\left.1 \mathrm{H}, \mathrm{CHCH}_{2} \mathrm{CO}_{2} \mathrm{CH}_{3} J=6.8 \mathrm{~Hz}\right) J=1 \mathrm{~Hz}\right), 2.41-2.37(\mathrm{~m}, 6 \mathrm{H}$, $\mathrm{NCH}_{2} \mathrm{CH}_{2} \mathrm{CH}_{2}$ ), 1.72-1.52 (m, $8 \mathrm{H}, \mathrm{CH}_{2} \mathrm{CH}_{2} \mathrm{CH}_{2} \mathrm{CH}_{2}$ ). Anal. calcd. (\%) for $\mathrm{C}_{15} \mathrm{H}_{23} \mathrm{NO}_{2}$ : C, 72.14; H, 9.19; N, 5.65. Found (\%): C, 72.20; H, 9.15; N, 5.60.

Methyl 1-(N- pyrrolidinyl)bicyclo[4.2.0]octene-8carboxylate (9): Methyl acetylenecarboxylate $1.2 \mathrm{~mL}$ (14.35 mmoles) in $50 \mathrm{~mL}$ of benzene was added slowly over a period of $2 \mathrm{~h}$ under nitrogen to solution of $1.2 \mathrm{~g}(8.0 \mathrm{mmol})$ of $1-(\mathrm{N}-$ pyrrolidin)cyclohexene at $0-7{ }^{\circ} \mathrm{C}$. The reaction mixture was stirred for $2 \mathrm{~h}$ at $0{ }^{\circ} \mathrm{C}$ and then stirring was continued for $20 \mathrm{~h}$ at room temperature. The solvent was evaporated. The residue purified by chromatography using silica gel chloroform. The crude product was recrystallized from petroleum ether to give 
$1.14 \mathrm{~g}(63 \%)$ of 9 , TLC: $\mathrm{R}_{\mathrm{f}} 0.72$ (ethyl acetate); m.p. $83^{\circ} \mathrm{C}$; IR $\left(\mathrm{KBr}, v_{\max }, \mathrm{cm}^{-1}\right)$ : $2943(\mathrm{~N}-\mathrm{C}), 2872\left(\mathrm{CH}_{2}\right), 1682(\mathrm{C}=\mathrm{O})$, $1591 \mathrm{C}=\mathrm{CH}, 1128(\mathrm{C}-\mathrm{O}) ;{ }^{1} \mathrm{H}{ }^{1} \mathrm{H}$ NMR $\left(\mathrm{CDCL}_{3}\right): \delta 7.60(\mathrm{~d}$, $1 \mathrm{H}, \mathrm{C}=\mathrm{CH}, J=12.84 \mathrm{~Hz}), 4.41(\mathrm{~d}, 1 \mathrm{H}, \mathrm{C}=\mathrm{CH}, J=12.84 \mathrm{~Hz})$, 3.66(s, 3H, $\left.\mathrm{OCH}_{3}\right), 3.643 .52\left(\mathrm{~m}, 4 \mathrm{H}, \mathrm{N}\left(\mathrm{CH}_{2}\right)_{2}\right), 2.10-1.86$ (m, 4H, $\mathrm{NCH}_{2} \mathrm{CH}_{2} \mathrm{CH}_{2}$ ) 1.67-1.58 (m,4H, $\left.\mathrm{CH}_{2}\right), 1.18-1.03$ (m, 2H, $\mathrm{CH}_{2}$ ), 0.81-0.79 (m, 2H, $\mathrm{CH}_{2}$ ); MS 70 eV, m/z 235.0 (86) $\left[\mathrm{M}^{+}\right], 220$ (32), 193 (30), 178 (100), 148 (34), 134 (32), 70 (42). Anal. calcd. (\%) for $\mathrm{C}_{14} \mathrm{H}_{21} \mathrm{NO}_{2}: \mathrm{C}, 71.39 ; \mathrm{H}, 8.92 ; \mathrm{N}$, 5.94. Found (\%): C, 71.42; H, 8.95; N, 5.9.

Methyl 2-(N-pyrrolidinyl)1-7-cyclooxtadiene-1-carboxylate (10): Compound 9 was refluxed in 1,4-dioxane for $8 \mathrm{~h}$. After the solvent was evaporated off and the residue was chromatographed using silica gel and ethyl acetate-dichloromethane (1:1). The crude products was recrystallized from diethyl ether to give 0.8 gr $(66 \%) \mathbf{1 0}$ as a pure white solid, m.p. $95^{\circ} \mathrm{C}$; IR ( $\left.\mathrm{KBr}, v_{\max }, \mathrm{cm}^{-1}\right): 3003(\mathrm{~N}-\mathrm{C}), 2957\left(\mathrm{CH}_{2}\right)$, $1713(\mathrm{C}=\mathrm{O}), 1633 \mathrm{C}=\mathrm{CH}, 1141(\mathrm{C}-\mathrm{O}) \mathrm{cm}^{-1} ;{ }^{1} \mathrm{H} \mathrm{NMR}\left(\mathrm{CDCl}_{3}\right)$ : $\delta 7.57(\mathrm{~d}, 1 \mathrm{H}, \mathrm{C}=\mathrm{CH}, J=12.16 \mathrm{~Hz}), 5.65(\mathrm{~d}, 1 \mathrm{H}, J=12.16$ $\mathrm{Hz}, \mathrm{C}=\mathrm{CH}), 3.74\left(\mathrm{~s}, 3 \mathrm{H}, \mathrm{OCH}_{3}\right), 3.71-3.68,\left(\mathrm{~m}, 4 \mathrm{H}, \mathrm{NCH}_{2} \mathrm{CH}_{2}\right)$, 1.57-1.30 (m, 6H, $\left.\mathrm{NCH}_{2} \mathrm{CH}_{2} \mathrm{CH}_{2}\right), 1.28-1.10\left(\mathrm{~m}, 6 \mathrm{H}, \mathrm{CH}_{2}\right)$. Anal. calcd. (\%) for $\mathrm{C}_{14} \mathrm{H}_{21} \mathrm{NO}_{2}$ : C, 71.20; H, 8.90; N, 5.91. Found (\%): C, 71.15; H, 5.88; N, 5.94.

Methyl 2-(N-pyrrolidinyl)1-7-cyclooxtadiene-1carboxylate (10): Methyl acetylenecarboxylate $1.2 \mathrm{~mL}$ (14.35 $\mathrm{mmol}$ ) in $50 \mathrm{~mL}$ of methanol was added slowly over a period of $2 \mathrm{~h}$ under nitrogen to a solution of $1.2 \mathrm{~g}(8.0 \mathrm{mmol})$ of 1 (pyrrolidin) cyclohexene at $0-7^{\circ} \mathrm{C}$. The reaction mixture was stirred for $2 \mathrm{~h}$ at $0{ }^{\circ} \mathrm{C}$ and then stirring was continued for $16 \mathrm{~h}$ at room temperature. The solvent was evaporated. The residue purified by chromatography using silica gel chloroform. The crude product was recrystallized from cyclohexane to give 1.3 g $(72 \%)$ of 10, m.p. $95^{\circ} \mathrm{C}$; TLC: $\mathrm{R}_{\mathrm{f}} 0.72$ (ethyl acetate); IR $\left(\mathrm{KBr}, v_{\max }, \mathrm{cm}^{-1}\right): 3003(\mathrm{~N}-\mathrm{C}), 2957\left(\mathrm{CH}_{2}\right), 1713(\mathrm{C}=\mathrm{O}), 1633$ $\mathrm{C}=\mathrm{CH}, 1141(\mathrm{C}-\mathrm{O}) \mathrm{cm}^{-1} ;{ }^{1} \mathrm{H}$ NMR $\left(\mathrm{CDCl}_{3}\right): \delta 7.57(\mathrm{~d}, 1 \mathrm{H}$, $\mathrm{C}=\mathrm{CH}, J=12.16 \mathrm{~Hz}), 5.65(\mathrm{~d}, 1 \mathrm{H}, J=12.16 \mathrm{~Hz}, \mathrm{C}=\mathrm{CH}), 3.74$ (s, 3H, $\left.\mathrm{OCH}_{3}\right), 3.71-3.68$, (m, 4H, $\left.\mathrm{NCH}_{2} \mathrm{CH}_{2}\right), 1.57-1.30$ (m, $\left.6 \mathrm{H}, \mathrm{NCH}_{2} \mathrm{CH}_{2} \mathrm{CH}_{2}\right)$, 1.28- $1.10\left(\mathrm{~m}, 6 \mathrm{H}, \mathrm{CH}_{2}\right)$. Anal. calcd. for $\mathrm{C}_{14} \mathrm{H}_{21} \mathrm{NO}_{2}$ : C, 71.21; H, 8.92; N, 5.94. Found (\%): C, 71.17; H, 5.87; N, 5.91 .

\section{RESULTS AND DISCUSSION}

The $[2+2]$ cycloaddition reactions of enamines with electrophilic olefines in polar and Non-polar solutions have been extensively studied in the literature ${ }^{1-3,13}$.

We reported herein the $[2+2]$ cycloaddition reactions of methyl acetylenecarboxylate in polar and non-polar solvents. It is observed that the cyclo butene ring and ring-expansion products are formed together in a single-step reaction of $[2+$ 2] cycloaddition reaction of 1-(N-morphonlinyl)cyclohexene (1) and methyl acetylenecarboxylate in benzene. The products, methyl 1-(N-morpholinyl)bicyclo[4.2.0]octene 8-carboxylate (2) (yield: $35 \%$ ) and methyl 2-(N-morpholinyl)-1,7-cyclooctadiene-1-carboxylate (3) (yield: $65 \%$ ), are determined by GC-MS. However, it is observed that methyl 2-(N-morpholinyl)-1,7-cyclooctadiene-1-carboxylate (3) is formed directly by the ring-expansion after the $[2+2]$ cycloaddition reaction in a polar solvent $e . g$. methanol, which shows that the $[2+2]$ cycloaddition reactions result in different products by the solvent effects. In a previous $s$ tudy ${ }^{3}$, it was reported that a ring-expansion product is formed in a single-step reaction of "1-(N-morphonlinyl)cyclohexene in DEAD" in benzene. In this study, it is observed that methyl 1-(N-morpholinyl)bicyclo[4.2.0]octene 8-carboxylate $(2)$ is formed as a [2+2] cycloaddition product, since methyl acetylenecarboxylate structure has a less electrophilic property. This observation shows the effects of electrophilic property on the reactions. In this reaction, another factor is the solvent effect and methyl 2(N-morpholinyl)-1,7-cyclooctadiene-1-carboxylate (3) is obtained in polar solvent e.g., methanol (Scheme-I). The cyclo butene ring is not expanded in the reaction of methyl acetylenecarboxylate and methyl 2-(N-piperydinyl)cyclohexene in benzene. However, the ring-expansion is observed when heated in 1,4-dioxane, which resulted with the formation of methyl 2-(N-piperidinyl)-1,7-cyclooxtadiene-1-carboxylate (6) (Scheme-II).

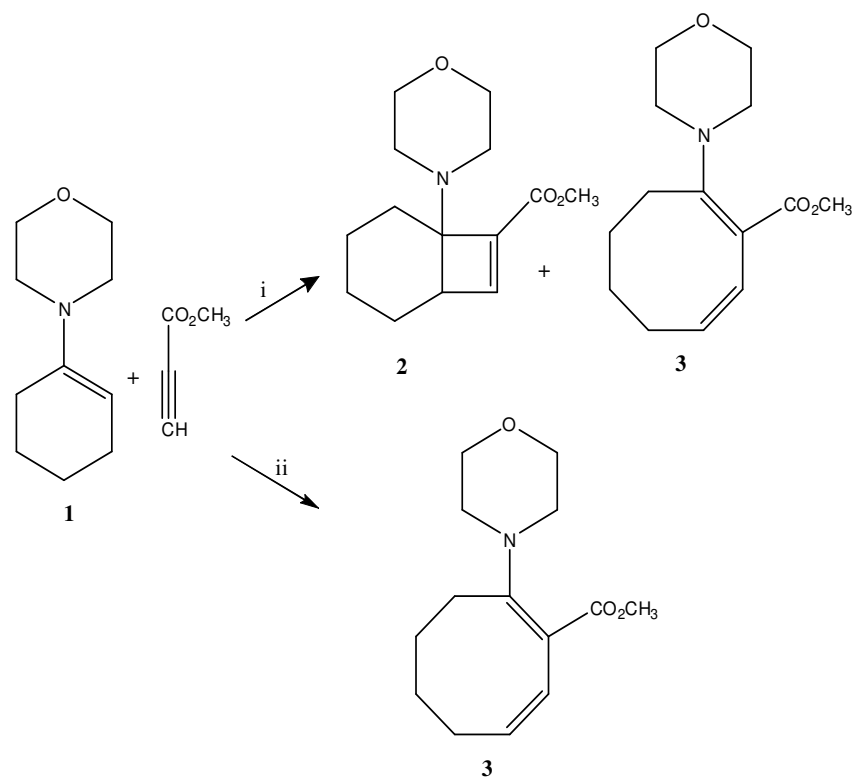

Scheme-I: (i) $0-5{ }^{\circ} \mathrm{C}$, in benzene; (ii), $0-5{ }^{\circ} \mathrm{C}$, in methanol

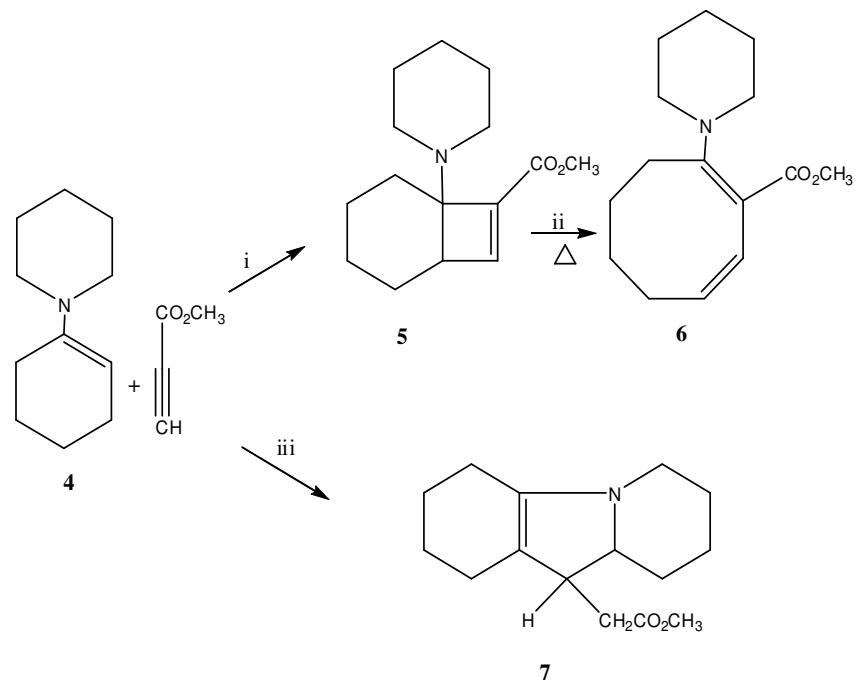

Scheme-II: (i) $0-5{ }^{\circ} \mathrm{C}$, in benzene; (ii) 1,4 -dioxane, reflux, $8 \mathrm{~h}$; (iii) $0-5{ }^{\circ} \mathrm{C}$, in methanol 
1-(N-Pyrrolidinyl)cyclohexene in benzene [2+2] cyclobutene adduct 9 could be isolated and then 9 was heated at $90{ }^{\circ} \mathrm{C}$ for $5 \mathrm{~h}$, the cycloisomerization product 10 was obtained (Scheme-III). However, 1-(N-pyrrolidinyl)cyclo-hexene in methanol was converted directly to ring-opened cycloisomerization 10 product in one step when allowed to react with methyl acetylenecarboxylate at $0-7^{\circ} \mathrm{C}$ (Scheme-II).

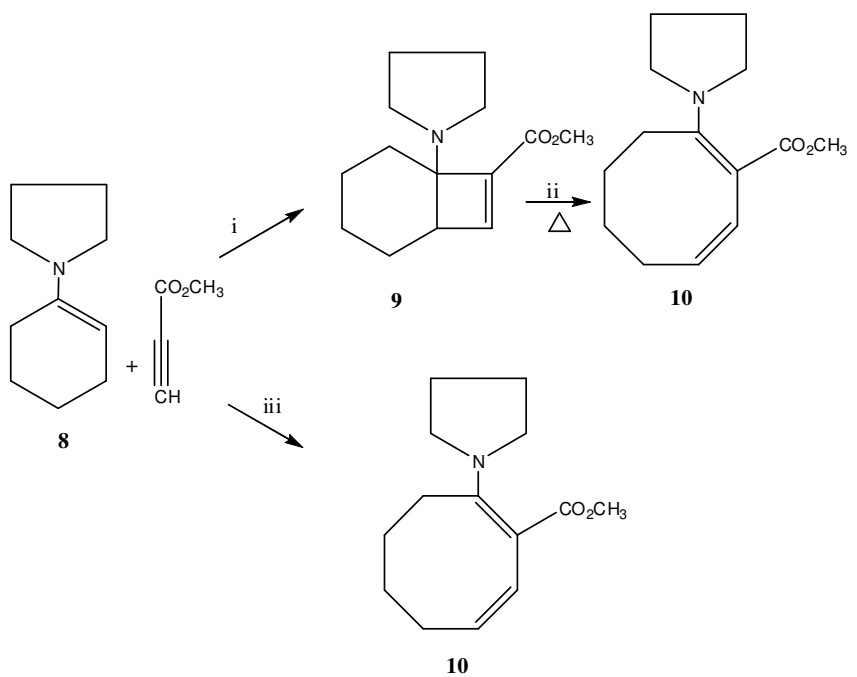

Scheme-III: (i) $0-5{ }^{\circ} \mathrm{C}$, in benzene; (ii) $1,4-$ dioxane, reflux, $8 \mathrm{~h}$, (iii) $0-5{ }^{\circ} \mathrm{C}$, in methanol

We have recently found that the solvent has a remarkable effect on the reactions of diethyl acetylenedicarboxylate (DEAD) and 1-piperidinyl enamines ${ }^{2}$. Whereas in polar solvents $[2+2]$ cycloaddition takes place, polar solvents like methanol pyrrolizines are formed by reaction of the initially formed lineer Michael adducts of enamines and diethyl acetylenedicarboxylate (DEAD).
Pyrrolizines are synthesized from the reaction of the methyl 2-(N-piperidinyl)cyclohexene and methyl acetylenedicarboxylate in methanol 7. The formation of pyrrolizine structures using pyrrolidinyl enamine with diethyl acetylenedicarboxylate (DMAD) and piperidine enamine with DEAD in protic polar solvents is reported by Reinhoudt et al. ${ }^{13}$, in the literature. In the present study, another important result is the reaction time, when the reaction times of pyrrolidine and piperidine enamines are compared, it is observed that pyyrolidine enamine $>$ piperidine enamine $>$ morpholine enamine. So, the nucleophilic effect of these ringed-enamines ia in the form of pyrrolidine $>$ piperidine $>$ morpholine.

\section{REFERENCES}

1. G.A. Berchtold and G.F. Uhlig, J. Org. Chem., 28, 1459 (1963).

2. A. Uzgoren-Baran, N. Tunoglu and G. Okay, Org. Prep. Proced. Int., 42, 143 (2010).

3. N. Tunoglu and N. Uludag, Org. Prep. Proced. Int., 29, 541 (1997).

4. C.F. Huebner, L. Dorfman, M.M. Robison, E. Donoghue, W.G. Pierson and P. Strachan, J. Org. Chem., 28, 3134 (1963).

5. E. Rossi, G. Abbiati, A. Arcadi and F. Marinelli, Tetrahedron Lett., 42, 3705 (2001).

6. A.G. Cook, Enamines Structure and Reactions, M. Dekker, New York; Ch. 7 pp. 1-384 (1988).

7. G. Kaupp, V. Pogodda, A. Alfah, H. Mier and A. Vierengel, Angew. Chem. Int. Ed., 31, 768 (1992).

8. H. Hongo, H. Nakano and Y. Okuyama, Heterocycles, 40, 831 (1995).

9. G. Stork, A. Brizzolara, H. Landesman, J. Szmuszkovicz and R. Terrell, J. Am. Chem. Soc., 85, 207 (1963).

10. G. Van Beek, J.L. Van Der Baan, G.W. Klumpp and F. Bickelhaupt, Tetrahedron, 42, 5111 (1986).

11. G. Stork and T.L. Macdonald, J. Am. Chem. Soc., 97, 1264 (1975).

12. A.K. Bose and G.L. Minah, Metropolitan Regional Meeting of the American Chemical Society, Newark New York, January 28 (1963).

13. D.N. Reinhoudt, W. Verboom, G.W. Visser, W.P. Trompenaars, S. Harkema and G.J. Van Hummel, J. Am. Chem. Soc., 106, 1341 (1984). 